\title{
Color changing and behavioral context in the Amazonian Dwarf Cichlid Apistogramma hippolytae (Perciformes)
}

\author{
Raoni Rosa Rodrigues ${ }^{1}$, Lucélia Nobre Carvalho ${ }^{2,3}$, Jansen Zuanon ${ }^{3}$ \\ and Kleber Del-Claro ${ }^{1}$
}

Animal coloration has many functions, and fishes are noted among vertebrates for presenting a wide variety of color patterns. Although in marine fishes the relationship between body coloration and behavioral context is well documented, there's not much information about freshwater fishes. Here we describe color patterns displayed by the dwarf cichlid Apistogramma hippolytae and suggest that these patterns are dependent on different social and behavioral settings. Field observations were conducted underwater in a pond in Central Amazonia, Brazil. We recorded six body coloration patterns related to seven different kinds of behavioral activities: foraging, resting, reproductive and agonistic displays, aggression (attacking and fleeing) and parental care. Changes in coloration occur rapidly and take only a few seconds. Females on parental care exhibited a unique pattern that are more persistent and probably manifests more slowly. In the shallow and clear waters of the natural environment of this dwarf cichlid, color communication seems to constitute an efficient way to display information about individual mood, social status and reproductive readiness, contributing to minimize loss of energy in unnecessary interactions.

Coloração animal tem diferentes funções, e os peixes se destacam entre os vertebrados por apresentarem uma grande diversidade de padrões de cores. Embora se conheça relativamente bem a relação entre coloração e contexto comportamental para peixes marinhos, pouco se sabe para os peixes de água doce. Nós descrevemos os padrões de coloração de um ciclídeo amazônico, Apistogramma hippolytae, e sugerimos como esses padrões são dependentes das características sociais e comportamentais. Realizamos observações subaquáticas utilizando mergulho livre em campo durante o dia em uma lagoa na Amazônia Central. Nós caracterizamos seis padrões de coloração associados a sete comportamentos diferentes: alimentação, repouso, displays sexual e agonístico, agressão (ataque e fuga) e cuidado parental. As mudanças de coloração levam apenas alguns segundos. Fêmeas em cuidado parental exibem um padrão exclusivo, cuja mudança é mais lenta. No ambiente natural desse ciclídeo, locais rasos com águas claras, a comunicação por coloração pode ser um sistema eficiente de comunicar o estado motivacional individual, status social e disposição para reprodução, possivelmente contribuindo para minimizar a perda de energia com interações desnecessárias.

Key Words: Intraspecific communication, Interspecific communication, Color changes, Parental care, Cichlidae.

\section{Introduction}

Animal colors may serve for different functions, such as thermoregulation, camouflage, and intra- and interspecific communication (Endler, 1978). Among vertebrates, fishes are notable for having a wide variety and intraspecific variation of color patterns, both in temporary and/or permanent conditions (Erisman \& Allen, 2005). The chromatophores of fishes are under neurocrine control, so that colors and patterns can be changed almost instantaneously (Kodric-Brown, 1998). This ability to change colors rapidly is used by fishes to send many kinds of signals in different social and environmental settings (Kodric-Brown, 1998). Moreover, the expression of different color patterns reflects changes in behavior of fishes,

${ }^{1}$ Laboratório de Ecologia Comportamental e de Interações (LECI), Universidade Federal de Uberlândia. Caixa Postal 593, 38400-902 Uberlândia, MG, Brazil. raonirosa@yahoo.com.br (RRR), delclaro@ufu.br (KDC)

${ }^{2}$ Instituto de Ciências Naturais, Humanas e Sociais (ICNHS), Universidade Federal de Mato Grosso (UFMT), Campus de Sinop. Av. Alexandre Ferronato, 1200, Setor Industrial, 78550-000 Sinop, MT, Brazil. carvalholh@yahoo.com.br

${ }^{3}$ Coordenação de Pesquisas em Biologia Aquática (CPBA), Instituto Nacional de Pesquisas da Amazônia (INPA) and Biological Dynamics of Forest Fragments Project (BDFFP), Smithsonian Tropical Research Institute. Caixa Postal 478, 69011-970 Manaus, AM, Brazil. zuanon@inpa.gov.br 
both in spatial and temporal scales.

In marine fishes, DeMartini (1985) has described six color patterns, including changes in color, brightness and stains, in the painted greenling Oxylebius pictus (Hexagrammidae). Nevertheless, the first behavioral evidence of the ability of fishes to discriminate colors is recent in literature (Siebeck et al., 2008). For reef fishes, there are evidences of seasonal color dimorphism between sexes (DeMartini \& Sikkel, 2006) and along the ontogeny (Lobel et al., 2009). Short duration variations in color pattern may occur during mating behavior or related to the use of different microhabitats (DeMartini \& Sikkel, 2006). Changes in color can also be associated with mimetic interactions (Moland \& Jones, 2004), or sex change (Ohta et al., 2008). For freshwater species, the knowledge is almost restricted to cichlid fishes. Baerends \& Baerends-van Roon (1950) describe color patterns in several species of cichlids, but scarcely relating these changes to specific behaviors. Other studies examine relationships between color and behavior, but strongly directing the observation to specific behaviors, like social status (Barlow, 1973; Falter, 1987; Barlow \& Siri, 1994; Korzan et al., 2008), sexual selection (Beeching et al., 1998; Römer \& Beisenherz, 2005), or intra(Baerends, 1993; Hurd, 1997) and interspecific communication (Ready et al., 2006). In addition to the cichlids, some studies address changes in coloration related to sexual selection of females in three-spined stickleback, Gasterosteus aculeatus (Rick \& Bakker, 2008); for camouflage in the chamaeleon characin, Ammocryptocharax elegans (Zuanon et al., 2006); and in the larvae and juveniles of white sturgeon Acipenser transmontanus (Kynard \& Parker, 2005).

Despite that, rare studies have quantified the relation between color changes and activities executed by fish, although changes in coloration related to mood in cichlids are well documented in aquarium literature (e.g. Römer, 2001). As far as we know, there are four studies quantifying coloration patterns of cichlids and associated behaviors. Baldaccini (1973) described nine color patterns related to 18 different behaviors in Tilapia mariae, and Neil (1984a, 1984b) described four color patterns in Cichlasoma meeki (= Thorichthys meeki) related to aggressive behavior, sexual and gonadal development. Hulscher-Emeis (1992) described the color patterns associated to 33 behaviors, separating them by sex and age class.

Here we describe the color patterns of Apistogramma hippolytae, a dwarf cichlid typical of clear and black waters in the Brazilian Central Amazon, aiming to determine how color patterns may be related to distinct behavioral contexts.

\section{Material and Methods}

The study was carried out between April and September 2005, in a pond near the research station of Dimona Farm (2²0'25.5114”'S 606'5.7594'W) in the Biological Dynamics of Forest Fragments Project area - BDFFP (INPA/Smithsonian Institute), distant $70 \mathrm{~km}$ north of Manaus, Brazil. The area is part of the Cuieiras River basin, a tributary of the Negro River. For a map and additional information about the study area see Bührnheim \& Cox-Fernandes (2001) and Gascon \& Bierregaard (2001).

The studied pond (approximately $40 \mathrm{~m}$ long $\mathrm{x} 14 \mathrm{~m}$ wide $\mathrm{x}$ $0.5 \mathrm{~m}$ deep) was formed approximately 15 years ago, due to the partial damming of a forest streamlet (locally known as igarapé) for the construction of a never-finished local road. The bottom of the pond is covered by a thick layer of finely particulate sediments and submerged dead leaves ( 80\%), and by trunks and twigs ( $20 \%)$. The pond is surrounded by primary and secondary tropical rain forest, making a mosaic of trees and shrubs that overhang the pond margins and contribute with organic matter to the aquatic system. Despite the presence of fine sediments the water was clear and enabled good underwater visualization.

Underwater behavioral observations during snorkeling sessions (cf. Sazima, 1986) were conducted in the field at daytime using the "focal animal" and "ad libitum" samplings (Lehner, 1996), totaling 18 hours of records. Each individual observation lasted for approximately 15 seconds and included the type of activity (feeding, resting, agonistic display, sexual display, attacking or fleeing), sex, age (juveniles or adults), estimated size of the individuals (when involved in intra- or interespecific interactions), and its color pattern. Quantitative data about behavioral categories and interactions were gathered by a single observer (RRR) that stayed motionless at a distance from the subjects in order to avoid disturbing the fish (Sabino, 1999). Color patterns were characterized following Baerends \& Baerends van-Roon (1950) and Römer (2001), describing general body color and emphasizing the presence of dark bands, stripes, and blotches in the head and body of the individuals (Fig. 1).

Frequency of occurrence was employed to quantify the relation between the observed behaviors and the color patterns displayed by the individuals during the observed events. Voucher specimens were deposited in the Fish Collection of the Instituto Nacional de Pesquisas da Amazônia, Manaus (INPA 26114 and INPA 26115).

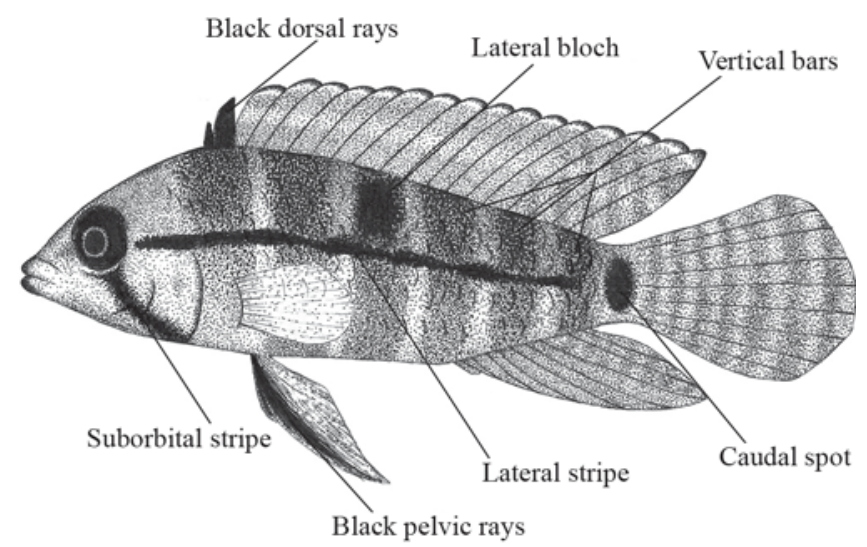

Fig. 1. Principal marks used to describe the colors of Apistogramma hippolytae. Based on Baerends \& Baerends van-Roon (1950) and Römer (2001). Drawing by D. B. LimaSilva. 


\section{Results}

A total of 1014 individual observations of A. hippolytae were recorded. Estimated size of the observed individuals ranged 35-70 mm total length. The individuals were observed forming aggregations along the shallow areas of the pond. These aggregations usually were composed by subgroups of 4-5 individuals, without a cohesive behavioral pattern. This grouping behavior seemed to be elicited mainly by external stimuli (e.g. food resources, R. R. Rodrigues, pers. observ.), generally with a non-territorial large male (over $60 \mathrm{~mm}$ TL), that precluded other individuals from remaining in its temporary foraging area.

Five different patterns of body coloration were recorded in A. hippolytae, based on variations in the intensity of the spots and bars exhibited (Figs. 2 and 3). Beyond these five patterns, a color pattern presented exclusively by brood-caring females was also recognized.

The most common color pattern was characterized by a silver-grey background color, with the lateral blotch and suborbital stripe absent or faint (Figs. 2a-b). This pattern was called "plain" and was observed mainly when the individuals were feeding ( $90 \%, \mathrm{n}=523$ occurrences; Fig. 3 ).

In the second most common pattern, called "stripe-spot" (Figs. 2c-d), the animal became pale, with conspicuous lateral stripe, lateral blotch and caudal spot. The eyes became darker, the suborbital stripe turned faint or absent and the lateral bars in the flanks became visible. This pattern was found mainly when the individuals were still above the substratum (resting, $89 \%, n=406$; Fig. 3); when disturbed by a sudden movement nearby; by the presence of a predator; or when involved in persecution/aggression events (fleeing, $32 \%, n=34$ ). This

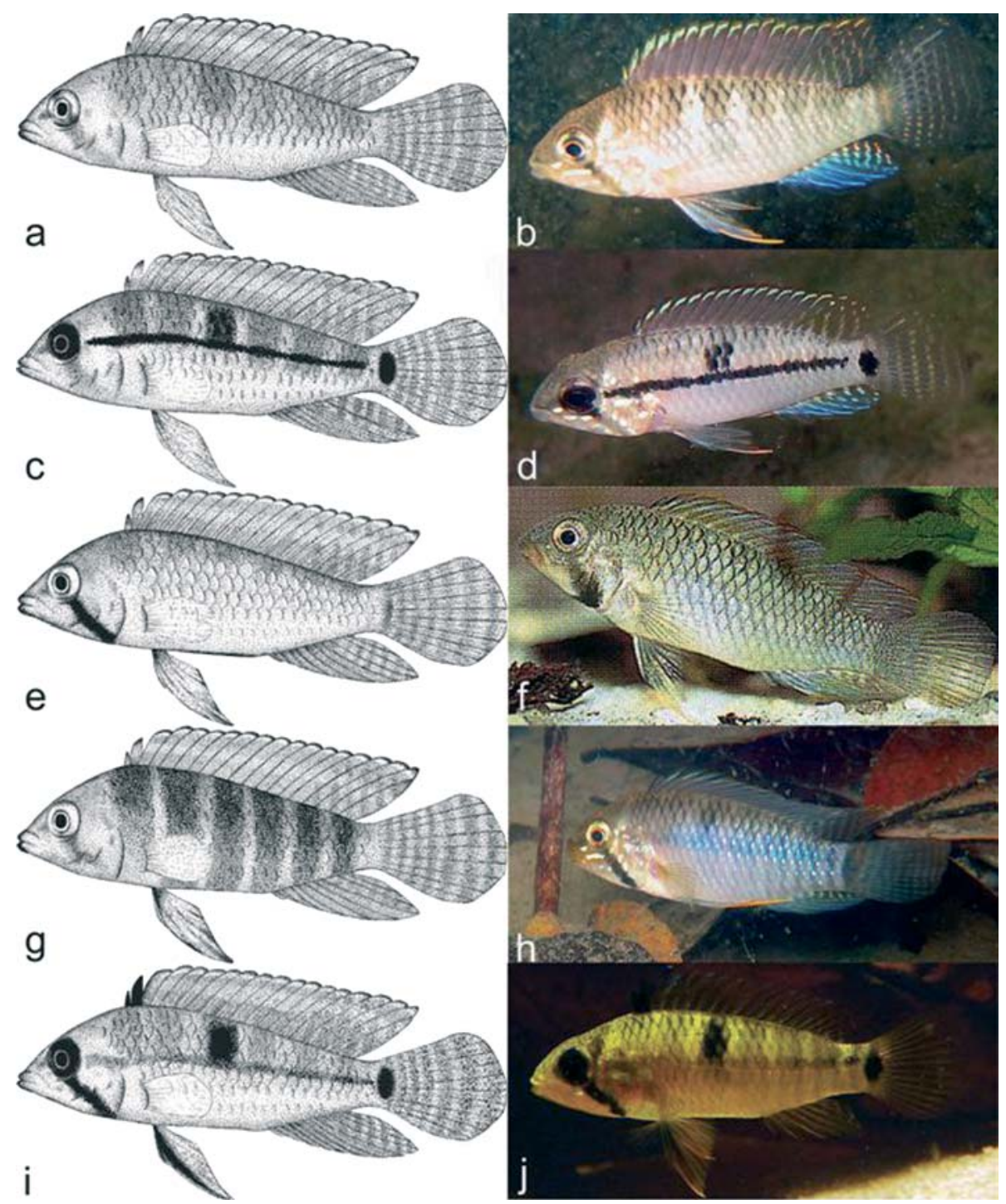

Fig. 2. Coloration patterns presented by Apistogramma hippolytae. a-b = "plain"; c- $\mathrm{d}$ = "stripe-spot"; e-f = "painted-face"; g = "barred"; $h$ = "shining"; i-j = female in parental care. For more details see text. Photos (b), (d), and (h) by J. Zuanon; (f) modified from Römer (2001); and (j) by F. Mendonça. Drawings by D. B. Lima-Silva. 
pattern was rarely observed in large males (over $60 \mathrm{~mm} \mathrm{TL}$ ).

The "painted-face" pattern (Figs. 2e-f) consisted of a silver-grey background without spots or stripes, except for the conspicuous suborbital stripe. It was registered mainly in large individuals, immediately before performing intra- or interspecific aggression (61\%, $n=36$; Fig. 3 ).

The "barred" pattern (Fig. 2g) was characterized by a general increase in the intensity and contrast of the body colors, with the presence of conspicuous dark brown lateral bars in the flanks (much more intense than in "stripe-spot" pattern). The suborbital stripe appeared with different degrees of conspicuousness. An increase in eye brightness was also noted. This pattern was only observed in five occasions, when individuals were engaged in agonistic display (Fig. 3).

Males engaged in courtship (Fig. 3) presented a typical color pattern named "shining". This pattern is similar to the "barred" one (Fig. 2h), but differs in the absence of lateral bars and by an increase in the intensity and contrast of the coloration of the ventral region.

Females on parental care exhibited a unique pattern, with the first rays of pelvic and dorsal fins strongly colored in black. Usually the lateral blotch, suborbital stripe and caudal spot were very conspicuous, and the lateral stripe was absent or faint (Fig. 2i). The overall grey ground color is substituted by an intense yellow tone (Fig. 2j).

Changes in coloration occurred rapidly (in a few seconds). For instance, when large male attack an intruder, it changes to "painted-face", drive way the fish and return to the "plain" pattern, less than $20 \mathrm{~s}$. When an agonistic display occurs, the fish involved change of "plain" to "barred" patterns, execute the behavior and then return to "plain" pattern, all this in less than $30 \mathrm{~s}$. On the other hand, the time needed by broodcaring females to change their coloration pattern was longer (not quantified).

\section{Discussion}

Quick changes in color pattern are a common characteristic of cichlids (Baldaccini, 1973; Neil, 1984a; Nelissen, 1991), due to the superficial position of the cromatophores producing the characteristic marks of each pattern (Baerends \& Baerends van-Roon, 1950; Hulscher-Emeis, 1992). The "plain" pattern probably constitutes a cryptic coloration, allowing the fish to be confounded with the pond substrate that is composed of light-colored organic debris. It was the most commonly observed pattern, occurring mainly when the fish were feeding undisturbed. Römer (2001) relates such color pattern with a neutral, calm mood. In fact, disturbances in the environment were usually followed by changing to the "stripe-spot" pattern. The presence of vertical bars composing the color pattern has been described for other cichlids and associated with escape and submission behaviors (Baerends \& Baerends-van Roon, 1950; Baldaccini, 1973; Falter, 1987; Beeching, 1995; O’Connor et al., 1999). The combination of spots, stripes and bars, associated with the reduction of the coloration intensity, seems to constitute a disruptive pattern, allowing the fish to stay unnoticed for potential predators (Endler, 1978). Nevertheless, more than 65\% of the fish observed fleeing after a disturbance showed the "plain" pattern (Fig. 3). This can be explained by the fact that the vast majority of the observed attacks (and escape responses) resulted from aggressive interactions (butting) by larger individuals of $A$. hippolytae during foraging, and not from predation attempts. In such cases, the individual attacked moved few centimeters away and was not harassed further. However, continued persecution by large pike cichlids (our observations), or sudden disturbances in the nearby environment was immediately followed by change to the "stripe-spot" pattern. This color pattern was also displayed by females during the courtship and may indicate a form of submission, avoiding attacks by persistent, aggressive males (Burchard, 1965; Baldaccini, 1973).

The very conspicuous suborbital stripe in the "paintedface" pattern seems to represent the main sign of aggression, and was also displayed by females engaged in parental care. The pattern described by Römer (2001) for slightly aggressive individuals do not agree with our observations, since that author mentions that the "painted-face" pattern predominates among captive fish. However, our observations indicate that such pattern was displayed predominantly by larger fishes

\section{Percentage}

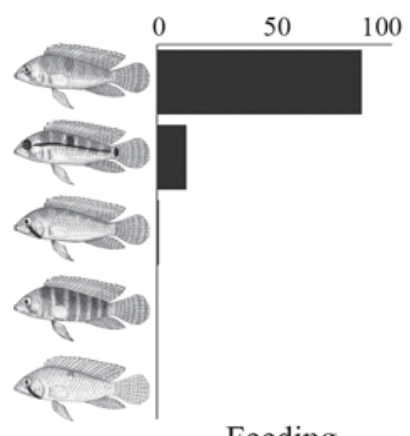

Feeding

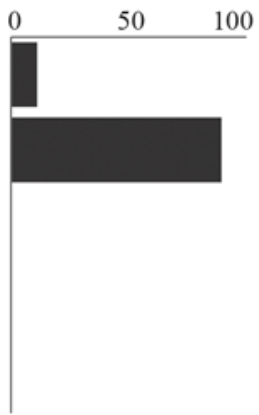

Resting

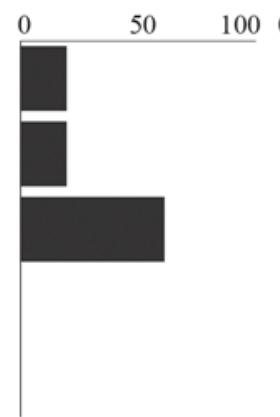

Attacking

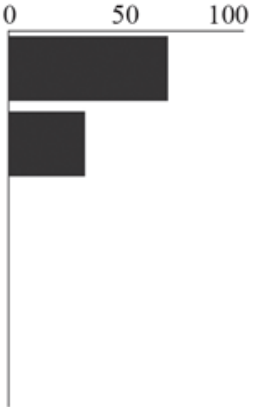

Fleeing

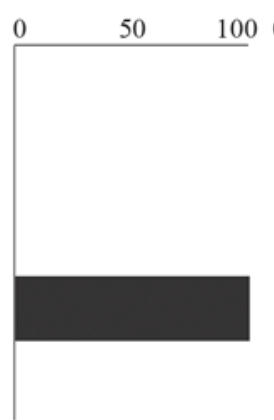

Agonistic display

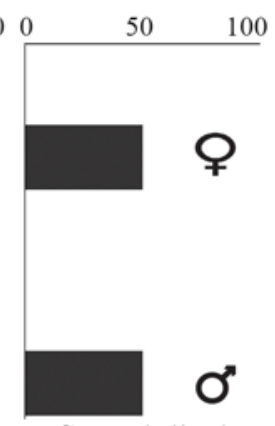

Sexual display

Fig. 3. Frequency of occurrence of five coloration patterns according to behaviour categories in Apistogramma hippolytae. 
and immediately before attacks by co-specifics. This would represent a warning coloration, indicating the imminence of an agonistic interaction (cf. Hurd, 1997).

The "shining" and "barred" patterns showed a considerable increase in the intensity of the background body color, which could be related to reproductive readiness (Neil, 1984a) and employed during courtship or in disputes for females, maybe a vigor sign (Maan et al., 2006, 2008). The yellowish color of brood-caring females is characteristic of Apistogramma species, as well as the increase in conspicuousness of blotches and spots (Burchard, 1965; see examples in Römer, 2001). The combination of yellow and black marks is recognized as one of the most common warning patterns in animals (Endler, 1978; Neil, 1984a) and may be related to the aggressiveness of brood-caring females. The conspicuous black marks on the fins, especially in the pelvics is believed to be related to the mother's communication with their offspring, as already noted by Baldacini (1973) and Baerends (1993).

In the shallow and clear waters inhabited by the dwarf cichlid Apistogramma hippolytae, color pattern changing has been suggested to be a very efficient communication system, avoiding loss of energy in unnecessary interactions (Hurd, 1997; Reddon \& Hurd, 2009). Studies that examine the physiological mechanisms or evolutionary context involved in the occurrence of color changes expression in Apistogramma species may help to elucidate the general aspects of the natural history of these dwarf cichlids.

\section{Acknowledgements}

We thank Rafael Arruda and Eduardo Bessa for the careful reading and for making important suggestions to the manuscript, and Fernando Mendonça and Uwe Römer for allowing the use of some images that illustrate this paper. We also thank the technicians of the Biological Dynamics of Forest Fragments Project (BDFFP), especially O. S. Pereira and Sr. Cardoso, for their help during fieldwork. BDFFP and INPA provided invaluable logistic and financial support. The Programa de Educação Tutorial (PET - SESu/MEC) financed RRR graduate studies. CNPq provided research grants to JZ and KDC, and Fapemig to KDC. CNPq, FAPEAM and "Fundação O Boticário" provided for financial support to Igarapés Project. This is contribution number 552 of BDFFP Technical Series and 19 of the Igarapés Project.

\section{Literature Cited}

Baerends, G. P. 1993. A comparative study of stimulus selection in the filial following response of fry of substrate spawning cichlid fish. Behaviour, 125(1-2): 79-155.

Baerends, G. P. \& J. M. Baerends van-Roon. 1950. An introduction to the study of the ethology of cichlid fishes. Behaviour, 1(Suppl.): 1-243.

Baldaccini, N. E. 1973. An ethological study of reproductive behavior including the color patterns of the cichlid fish Tilapia mariae (Boulanger). Monitore Zoologico Italiano, 7: 247-290.
Barlow, G. W. 1973. Competition between color morphs of the polychromatic midas cichlid Cichlasoma citrinellum. Science, 179(4075): 806-807.

Barlow, G. W. \& P. Siri. 1994. Polychromatic Midas cichlids respond to dummy opponents - color, contrast and context. Behaviour, 130: 77-112.

Beeching, S. C. 1995. Color pattern and inhibition of aggression in the cichlid fish Astronotus ocellatus. Journal of Fish Biology, 47: 50-58.

Beeching, S. C., S. H. Gross, H. S. Bretz \& E. Hariatis. 1998. Sexual dichromatism in convict cichlids: The ethological significance of female ventral coloration. Animal Behaviour, 56: 1021-1026.

Bührnheim, C. M. \& C. Cox-Fernandes. 2001. Low seasonal variation of fish assemblages in Amazonian forest streams. Ichthyological Exploration of Freshwaters, 12(1): 65-78.

Burchard, J. E. 1965. Family structure in the dwarf cichlid Apistogramma trifasciatum Eigenmann and Kennedy. Zeitschieft fur Tierpsychologie, 22: 150-162.

DeMartini, E. E. \& P. C. Sikkel. 2006. Reproduction. Pp. 483-523. In: Allen, L. G., D. J. Pondella \& M. H. Horn (Eds.). The Ecology of Marine Fishes: California and Adjacent Waters. Berkeley, University of California Press, 660p.

DeMartini, E. E. 1985. Social behavior and coloration changes in painted greenling, Oxylebius pictus (Pisces: Hexagrammidae). Copeia, 1985(4): 966-975.

Endler, J. A. 1978. A predators view of animal color patterns. Evolution Biology, 11: 319-364.

Erisman, B. E. \& L. G. Allen. 2005. Color patterns and associated behaviors in the Kelp Bass, Paralabrax clathratus (Teleostei: Serranidae). Bulletin of Southern California Academy of Science, 104(2): 45-62.

Falter, U. 1987. Description of the color patterns in Oreochromis niloticus (Teleostei, Cichlidae). Annales de la Societe Royale Zoologique de Belgique, 117: 201-219.

Gascon, C. \& R. O. Bierregaard. 2001. The Biological Dynamics of Forest Fragments Project: the study site, experimental design, and research activity. Pp. 31-42 . In: Bierregaard, R. O., C. Gascon, T. E. Lovejoy \& R. Mesquita (Eds.). Lessons from Amazonia: the ecology and conservation of a fragmented forest. New Haven, Yale University Press, 496p.

Hulscher-Emeis, T. M. 1992. The variable color patterns of Tilapia zillii (Cichlidae) - integrating ethology, chromatophore regulation and the physiology of stress. Netherlands Journal of Zoology, 42(4): 525-560.

Hurd, P. L. 1997. Cooperative signalling between opponents in fish fights. Animal Behaviour, 54: 1309-1315.

Kodric-Brown, A. 1998. Sexual dichromatism and temporary color changes in the reproduction of fishes. American Zoologist, 38 : 70-81.

Korzan, W. J., R. R. Robison, S. Zhao \& R. D. Fernald. 2008. Color change as a potential behavioral strategy. Hormones and Behavior, 54(3): 463-470.

Kynard, B. \& E. Parker. 2005. Ontogenetic behavior and dispersal of Sacramento River white sturgeon, Acipenser transmontanus, with a note on body color. Environmental Biology of Fishes, 74(1): 19-30.

Lehner, P. N. 1996. Handbook of ethological methods. Cambrigde, Cambrigde University Press, 672p.

Lobel, P. S., L. A. Rocha \& J. E. Randall. 2009. Color phases and distribution of the western Atlantic labrid fish, Halichoeres socialis. Copeia, 2009(1): 171-174. 
Maan, M. E., M. Van Der Spoel, P. Q. Jimenez, J. J. M. Van Alphen \& O. Seehausen. 2006. Fitness correlates of male coloration in a Lake Victoria cichlid fish. Behavioral Ecology, 17: 691-699.

Maan, M. E., A. M. C. Van Rooijen, J. J. M. Van Alphen \& O. Seehausen. 2008. Parasite-mediated sexual selection and species divergence in Lake Victoria cichlid fish. Biological Journal of the Linnean Society, 94: 53-60.

Moland, E. \& G. P. Jones. 2004. Experimental confirmation of aggressive mimicry by a coral reef fish. Oecologia, 140: 676683.

Neil, S. J. 1984a. Color pattern variability and behavioral correlates in the firemouth cichlid, Cichlasoma meeki. Copeia, 1984(2): 534-538.

Neil, S. J. 1984b. Field studies of the behavioral ecology and agonistic behavior of Cichlasoma meeki (Pisces: Chiclidae). Environmental Biology of Fishes, 10(1-2): 59-68.

Nelissen, M. H. J. 1991. Communication. Pp. 225-239. In: Keenleyside, M. H. A. (Ed.). Cichlid fishes: behavior, ecology and evolution. London, Chapman \& Hall, 404p.

O’Connor, K. I., N. B. Metcalfe \& A. C. Taylor. 1999. Does darkening signal submission in territorial contests between juvenile Atlantic salmon, Salmo salar? Animal Behaviour, 58: 1269-1276.

Ohta, K., M. Hirano, T. Mine, H. Mizutani, A. Yamaguchi \& M. Matsuyama. 2008. Body color change and serum steroid hormone levels throughout the process of sex change in the adult wrasse, Pseudolabrus sieboldi. Marine Biology, 153: 843852.

Ready, J. S., I. Sampaio, H. Schneider, C. Vinson, T. dos Santos \& G. F. Turner. 2006. Color forms of Amazonian cichlid fish represent reproductively isolated species. Journal of Evolutionary Biology, 19: 1139-1148.

Reddon, A. R. \& P. L. Hurd. 2009. Differences in aggressive behavior between convict cichlid color morphs: amelanistic convicts lose even with a size advantage. Acta Ethologica, 12: 49-53.

Rick, I. P. \& T. C. M. Bakker. 2008. Color signaling in conspicuous red sticklebacks: do ultraviolet signals surpass others? BMC Evolutionary Biology, 8: 189-198.

Römer, U. 2001. Baensch/Mergus Cichlid Atlas. Berlin, Mergus Publisher, 1310p.

Römer, U. \& W. Beisenherz. 2005. Intra- and interspecific mate choice of female Apistogramma cacatuoides (Teleostei: Cichlidae). Ichthyological Exploration of Freshwaters, 16(4): 339-345.

Sabino, J. 1999. Comportamento de peixes em riachos: métodos de estudo para uma abordagem naturalística. Pp. 183-208. In: Caramashi, E. P., R. Mazzoni \& P. R. Peres-Neto (Eds.). Ecologia de peixes de riachos. Série Oecologia Brasiliensis. Vol. 6. Rio de Janeiro, PPGE-UFRJ, 260p.

Sazima, I. 1986. Similarities in feeding behavior between some marine and freshwater fishes in two tropical communities. Journal of Fish Biology, 29: 53-65.

Siebeck, U. E., G. M. Wallis \& L. Litherland. 2008. Color vision in coral reef fish. Journal of Experimental Biology, 211: 354-360.

Zuanon, J., L. N. Carvalho \& I. Sazima. 2006. A chamaeleon characin: the plant clinging and color-changing Ammocryptocharax elegans (Characidiinae: Crenuchidae). Ichthyological Exploration of Freshwaters, 17(3): 225-232. 